\title{
ANALISIS SOSIO-YURIDIS PEMEKARAN KABUPATEN BALANIPA
}

\author{
Sulaeman \\ Dosen Prodi Ilmu Hukum Universitas Sulawesi Barat \\ Email: sulaeman@gmail.com
}

\begin{abstract}
Abstrak
Peran elite lokal Pembentukan daerah otonom Kabupaten Balanipa mengesankan pembangunan dan komunikasi pada Pemerintah pusat dengan proses penyiapan teknokratis/administrasi atas sejumlah kekurangan persyaratan morathorium Rancangan Undang-Undang (RUU). Kebijakan pemekaran daerah berdasar PP No. 78 Tahun 2007 justru lebih menekankan pada proses-proses ruang politik. Meskipun nampak ada sejumlah permasalahan mendasar yang dapat menyebabkan terjadinya pembentukan Kabupaten Balanipa namun demikian semua elite tersebut tidak akan mencapai hasil seperti sekarang kalau tidak ada campur tangan elite lokal, regional, dan pusat. Semua permasalahan tersebut merupakan kombinasi elite yang sangat kuat yang oleh elite lokal, regional, dan pusat.

Pada tingkat masyarakat perjuangan pembentukan Kabupaten Balanipa didasarkan pada kesadaran kolektif berbasis teritori-etnik dari tokoh masyarakat (civil society) memaksa mereka untuk bekerjasama dengan pejabat negara demi memperjuangan kejayaan masa lalu sebagai wilayah bekas kerajaan sebagai wilayah administrasi Kerajaan Balanipa. Landasan ide tersebut kemudian dijadikan upayakonsolidasi dengan para elite di aras lokal. Dimana peran masyarakat yakni mobilisasi massa sebagai bagian dari wujud aspirasi masyarakat dalam upaya mengontrol keputusan penetapan Pembentukan kabupaten Balanipa di ruang Rapat Badan Legislasi Nasional (Baleg) DPR RI pemerintah pusat.
\end{abstract}

Kata kunci: Analisis Sosio-Yuridis, Pemakaran, Kabupaten Balanipa

\section{Pendahuluan}

Wilayah Negara Indonesia yang sangat besar dengan rentang geografis yang luas berupa kepulauan, kondisi sosial-budaya yang beragam, jumlah penduduk yang besar, hal ini berpengaruh terhadap proses pengalokasian pembangunan itu dan proses pelaksanaan pemerintahan Negara Indonesia. Kondisi seperti ini menyebabkan pemerintah sulit mengkoordinasi pemerintahan yang ada di daerah. Maka untuk memudahkan pengaturan atau penataan pemerintahan diperlukan adanya suatu sistem pemerintahan yang dapat berjalan secara efisien dan mandiri tetapi tetap terawasi dari pusat.

Desentralisasi memberikan kesempatan kepada rakyatnya untuk ikut serta dalam pemerintahan, hal ini demi terlaksananya demokrasi dari bawah, di dalam wilayah Negara terdapat masyarakat-masyarakat yang memiliki kebutuhan/kepentingan yang berbeda antara satu daerah dengan daerah lain. Desentralisasi di Indonesia adalah sebuah peluang bagi pemerintah daerah untuk mengembangkan wacana politik lokal, selain itu desentralisasi telah memberikan ruang bagi suatu daerah untuk pembentukan daerah baru. Fenomena pemekaran daerah yang begitu cepat ini pastilah memiliki dampak yang sangat besar dalam konteks ekonomi, sosial, politik, dan pemerintahan. 
Sesuai dengan Peraturan Pemerintah No.78 Tahun 2007 Tentang Tata Cara Pembentukan Penghapusan, dan Penggabungan Daerah, maka syarat yang harus dipenuhi dalam pemekaran Kabupaten meliputi syarat administratif, teknis, dan fisik kewilayahan. Kemudian syarat teknisnya meliputi faktor kemampuan ekonomi, potensi daerah, sosial budaya, sosial politik, kependudukan, luas daerah, pertahanan, keamanan, kemampuan keuangan, tingkat kesejahteraan masyarakat, dan rentang kendali penyelenggaraan pemerintahan daerah. Sedangkan syarat fisik kewilayahan meliputi cakupan wilayah, lokasi calon ibukota, sarana dan prasarana pemerintahan.

Persetujuan DPRD dalam hal ini diwujudkan dalam bentuk Keputusan DPRD, yang diproses berdasarkan pernyataan aspirasi sebagian besar masyarakat setempat, sedangkan persetujuan gubernur didasarkan pada hasil kajian tim yang khusus dibentuk oleh pemerintah provinsi yang bersangkutan. Tim dimaksud mengikutsertakan tanaga ahli sesuai kebutuhan (Rozali Abdullah, 2005: 11).

Pada dasarnya pembentukan daerah otonom adalah untuk kemandirian suatu daerah, oleh sebab itu daerah dituntut untuk memenuhi persyaratan tersebut.

Hasil pengkajian menunjukkan bahwa seluruh komponen penilaian baik untuk calon Kabupaten Balanipa maupun Kabupaten Polewali Mandar Induk mencapai batas minimal skor yang ditentukan. Maka dari itu, prosedur pembentukan daerah baru melalui kebijakan pemekaran Wilayah di Kabupaten Balanipa ini dapat dinyatakan layak dan dapat dilanjutkan.

Dari uraian tersebut diatas kami tertarik untuk mengkaji secara "Sosio-Yuridis Pemekaran Kabupaten Balanipa".

A. Rumusan Masalah

Berdasarkan latar belakang di atas, beberapa pertanyaan yang akan dijawab dalam penelitian ini adalah:

1. Bagaimanakah peran masyarakat terhadap pembentukan Kabupaten Balanipa

2. Bagaimanakah dukungan Pemerintah atas Pembentukan Kabupaten Balanipa.

C. Tujuan Dan Kegunaan Penelitian

Berdasarkan rumusan masalah di atas, maka secara umum peneliti bertujuan untuk menderesearchkan dan Analisis Proses Pembentukan Kabupaten Balanipa. Secara khusus penelitian memiliki Tujuan dan Kegunaan sebagai berikut;

1. Penelitian bertujuaan;

a. Untuk Menggambarkan Bagaimana peran masyarakat terhadap pembentukan Kabupaten Balanipa;

b. Untuk mengetahui Bagaimana bentuk dukungan pemerintah atas pembentukan Kabupaten Balanipa.

2. Kegunaan Penelitian;

a. Memperkaya literatur secara teori serta bahan kajian ilmu politik dan hukum dalam upaya perkembangan disiplin keilmuan.

b. Menggambarkan fenomena sosial dan hukum yang ada. 
c. Menganalisis secara sosio-yuridis Proses Pembentukan Kabupaten Balanipa terutama Studi tentang Peranan Masyarakat dan dukungan Pemerintah kabupaten Polewali Mandar atas pembentukan Kabupaten Balanipa;

d. Penelitian ini dapat dijadikan sebagai bahan acuan dan pembelajaran di penelitian-penelitian berikutnya. Terkait analisis proses Pembentukan Kabupaten Balanipa;

\section{Tinjauan Pustaka}

\section{A. Otonomi Daerah}

Perjalanan otonomi daerah di Indonesia sudah dimulai sejak bangsa ini merdeka tahun 1945, hal ini tertuang dalam Undang-Undang No 1 Tahun 1945, tentang Peraturan Mengenai Kedudukan Komite Nasional Daerah, didalam Undang-undang ini mengamanatkan ada pembentukan Komite Nasional Daerahdi berbagai daerah di Indonesia.Jika ditelusuri lebih jauh Pemerintah Kolonial Belanda tahun 1903 telah mempelopori Undang-undang tentang Desentralisasi (B.N Marbun, 2010).

Berdasarkan Pasal 1 Undang-Undang Nomor 32 Tahun 2004 tentang Pemerintahan Daerah menyatakan bahwa :

Otonomi daerah adalah hak, wewenang, dan kewajiban daerah otonom untuk mengatur dan mengurus sendiri urusan pemerintahan dan kepentingan masyarakat setempat sesuai dengan peraturan perundang-undangan.Daerah otonom, selanjutnya disebut daerah, adalah kesatuan masyarakat hukum yang mempunyai batas-batas wilayah yang berwenang mengatur dan mengurus urusan pemerintahan dan kepentingan masyarakat setempat menurut prakarsa sendiri berdasarkan aspirasi masyarakat dalam sistem Negara Kesatuan Republik Indonesia.

Menurut Andi Malarangeng yang dikutip oleh HAW.Widjaja dalam Otonomi Daerah dan Daerah Otonom (2011: 117), otonomi daerah jangan membebani masyarakat, tetapi bagaimana memberikan kesejahteraan kepada masyarakat. Bila dampaknya justru mengakibatkan biaya ekonomi tinggi yang membebani masyarakat, hal itu bertentangan dengan semangat otonomi daerah.

Diharapkan dengan berjalannya otonomi daerah dapat memacu pemerataan pembangunan yang hasilnya untuk meningkatkan kesejahteraan masyarakat. Selain itu, otonomi daerah lebih diperuntukkan agar masyarakat dapat berperan aktif dalam membangun daerahnya masing-masing, sehingga potensi daerah tersebut dapat tergali secara optimal.

Berdasarkan pendapat yang dikemukakan oleh para ahli di atas, maka dalam hal ini dapat disimpulkan bahwa otonomi daerah merupakan suatu hak yang diberikan oleh pemerintah pusat kepada pemerintah daerah untuk menjalankan urusan rumah tangga daerahnya sendiri disertai pengawasan dari pusat. Dalam hal ini masyarakat diharapkan berperan aktif dengan tujuan adanya kemandirian untuk mengelola daerahnya sesuai dengan potensi daerah masing-masing, serta adanya kesiapan daerah dalam menyambut 
otonomi daerah ini. Dimana pihak yang bertanggungjawab untuk menjalankan proses pembagunan daerah adalah pemerintah daerah tersebut.

\section{B. Pemekaran Daerah}

Berdasarkan Peraturan Pemerintah (PP) No. 78 Tahun 2007 Tentang Tata Cara Pembentukan, Penghapusan, dan Penggabungan Daerah, Pemekaran Daerah merupakan pemecahan Provinsi atau Kabupaten/kota menjadi dua daerah atau lebih. Dalam hal pemekaran ini dapat berupa pembentukan daerah yaitu pemberian status pada wilayah tertentu sebagai daerah provinsi atau daerah Kabupaten/kota. Penghapusan daerah yaitu pencabutan status sebagai daerah Provinsi atau daerah Kabupaten/kota dan penggabungan daerah yang merupakan penyatuan daerah yang dihapus ke dalam daerah lain yang bersandingan.

Berbicara tentang pemekaran daerah tidak terlepas dari teori desentralisasi, sebagai wujud dari tuntutan akan penerapan prinsip-prinsip demokrasi dalam kehidupan bernegara. Namun jika dilihat lebih jauh apakah prinsip tersebut merupakan prinsip yang berasal dari partisipasi masyarakat.

\section{Merode Penelitian}

\section{A. Jenis Penelitian}

Jenis penelitian ini adalah deskriptif kualitatif, yaitu penulis berupaya mencari fakta-fakta sesuai dengan ruang lingkup judul penelitian, kemudian menggambarkan suatu fenomena yang diteliti secara apa adanya di lapangan. Menurut Sugiyono (2005:11)

"Penelitian deskriptif adalah penelitian yang dilakukan untuk mengetahui variabel mandiri, baik satu variabel maupun lebihtanpa membuat perbandingan atau menghubungkan satu variabel dengan variabel yang lain.”

Dalam kaitannya dengan penelitian ini, untuk mendapatkan berbagai gambaran dan permasalahan dalam analisa penyebab pemekaran Kabupaten Balanipa.

\section{B. Subjek Penelitian}

Adapun yang menjadi subjek dalam penelitian ini adalah Kabupaten Balanipa.

C. Objek Penelitian

Adapun yang menjadi objek penelitian ini adalah tokoh-tokoh masyarakat yang tergabung dalam kecamatan persiapan kabupaten Balanipa, karena daerah ini direncanakan sebagai daerah pemekaran.

\section{Informan}

Informan merupakan orang yang berada di lokasi penelitian, yang berhubungan dengan penelitian ini sehingga penulis mendapatkan informasi yang dibutuhkan dari informan tersebut. Kemudian Ketua BAPPEDA Polewali Mandar serta salah satu staff yang berada di BAPPEDA Kabupaten Polewali Mandar sebagai Key informan, selain pejabat terkait dengan penelitian ini juga para tokoh masyarakat Balanipa.

\section{E. Sumber Data}

Dalam penelitian ini sumber data yang dipergunakan yaitu:

a. Data primer 
Data primer yaitu data pokok yang didapat langsung dari lokasi penelitian, diproses dari responden yang menjadi sasaran penelitian yang meliputi data tentang pemekaran, dan dilakukan oleh pemerintah daerah Kabupaten Polewali Mandar khususnya penyebab keinginan masyarakat Balanipa untuk memekarkan daerahnya.

b. Data sekunder

Data yang dikumpulkan untuk suatu maksud yang lain tetapi digunakan kembali oleh analisis dalam suatu desain riset yang baru."

\section{F. Teknik Pengumpulan Data}

Dalam pengumpulan data penulis menggunakan beberapa teknik, sebagai berikut:

a. Observasi

Observasi adalah penulis melakukan pengamatan langsung ke lapangan obyek yang dilihat berdasarkan fakta-fakta yang terdapat di lokasi penelitian tersebut.

b. Wawancara

Wawancara adalah penulis melakukan tanya jawab secara langsung untuk mendapatkan informasi kepada kepala BAPPEDA Polewali Mandar dengan alat yang digunakan adalah pedoman wawancara yang disusun terlebih dahulu, dan penulis menggunakan teknik wawancara terbuka.

\section{G. Teknik Analisa Data}

Analisa data dalam penelitian ini adalah menggunakan secara deskriptif kualitatif, di mana penulis mengulas atau menggambarkan sesuai dengan kenyataan dan fenomena yang terjadi pada saat keluarnya isu pemekaran daerah Kabupaten Polewali Mandar sampai proses pemekaran Kabupaten Polewali Mandar berkembang menjadi Kabupaten Balanipa.

\section{Hasil Penelitian dan Pemabahasa}

\section{A. Kondisi Masyarakat}

Balanipa merupakan salah satu kecamatan yang ada di kabupaten Polewali Mandar. Dikecamatan Balanipa ini banyak terdapat potensi yang memungkinkan kecamatan ini dijadikan sebagai sebuah Kabupaten. Potensi yang dimaksud disini meliputi potensi dari segi pariwisata, pertambangan, pertanian, perkebunan dan budaya. Selain itu seperti yang telah diketahui bahwa, Secara history Balanipa ini juga merupakan salah satu kerajaan besar dari sekian banyak kerajaan besar yang ada di daerah mandar yang merupakan Kerajaan yang terhimpun dalam “Appe Banua Kayyang”.

Dalam pembentukan menjadi sebuah Daerah Otonom Baru (DOB), Ada beberapa Kecamatan kemudian yang nantinya bergabung di Kecamatan Balanipa itu sendiri apabila Kecamatan Balanipa ini terwujud menjadi sebuah Kabupaten. Kecamatan Kecamatan yang peneliti maksud disini adalah kecamatan Tinambung, Campalagian, Tu'bi Taramanu, Luyo,Limboro dan Alu. Semua kecamatan yang dimaksud ini memiliki potensi yang hampir sama dengan kecamatan Balanipa. Potensi inilah yang menjadi faktor pendorong mengapa kemudian beberapa kecamatan tersebut ingin di bentuk dan 
memisahkan diri dari Kabupaten Induknya Polewali Mandar dan menjadi salah satu kabupaten yang ada di Sulawesi barat.

Sebelum peneliti menjelaskan potensi dari kecamatan Balanipa, terlebih dahulu penulis akan menggambarkan secara umum tentang kondisi Geografis, Kependudukan, Pemerintahan dari kecamatan Balanipa.

Kondisi geografis apabila Balanipa menjadi sebuah kabupaten, Kabupaten Balanipa mempunyai Batas-batas Wilayah:

a) Sebelah Utara : Berbatasan dengan Desa Panggalo Kecamatan Ulumanda Kabupaten Majene, Desa Boting dan Passembu Kecamatan Mambi Kabupaten Mamasa

b) Sebelah Timur : Berbatasan dengan Kurma, Mapilli, Desa Bonra, Desa Sattoko, Dan Desa Rumpa Kecamatan Mapilli, Desa Daala timur, Desa Pulliwa, dan Desa Lenggo dan Kecamatan Bulo Kabupaten Polewali Mandar.

c) Sebelah Selatan : Berbatasan dengan Teluk Mandar

d) Sebelah Barat : Berbatasan dengan Desa Limboro kecamatan Sendana, Desa Tallambalao dan Desa Seppong Kecamatan Tamerodo, Desa Mayamba Kecamatan Tamerodo Sendana, Desa Mosso, Kecamatan Pamboang, Desa Tande, Desa Baruga dhua Kecamatan Banggae timur Kabupaten Majene.

Luas wilayah secara keseluruhan dari beberapa kecamatan yang nantinya tergabung dalam Kabupaten Balanipa adalah 991,16 km2.Dengan rincian sebagai berikut:

\begin{tabular}{|c|c|}
\hline \multicolumn{2}{|c|}{ Tabel 1 } \\
\hline Luas Wilayah Menurut Kecamatan persiapan Kabupaten Balanipa 2015 \\
\hline Kecamatan & Luas (km persegi) \\
\hline$(1)$ & $(2)$ \\
\hline Tinambung & 19,10 \\
\hline Balanipa & 34,9 \\
\hline Limboro & 63,22 \\
\hline Tubbi Taramanu & 441,84 \\
\hline Alu & 180,19 \\
\hline Campalagian & 128,35 \\
\hline Luyo & 124,27 \\
\hline Jumlah & $\mathbf{9 9 1 , 1 6}$ \\
\hline
\end{tabular}

Sumber : Badan Pusat Statistik Polewali Mandar, Polewali Mandar Dalam Angka 2017

Melihat kependudukan yang ada di Kecamatan Balanipa dan Kecamatankecamatan lain yang dimana nantinya akan tergabung dalam wilayah Kabupaten Balanipa itu sendiri, dapat kita lihat bersama bahwa wilayah yang memiliki kepadatan penduduk paling sedikit terdapat pada kecamatan Tubbi taramanu yaitu $52 \mathrm{jiwa} / \mathrm{Km} 2$ dan wilayah yang memiliki kepadatan penduduk paling banyak terdapat pada kecamatan Tinambung. yaitu 1059 jiwa / Km2. Dengan rincian sebagai berikut : 


\begin{tabular}{|c|c|c|}
\hline \multicolumn{3}{|c|}{ Luas Wilayah dan Jumlah Penduduk Menurut Kecamatan persiapan } \\
Kabupaten Balanipa, 2015 \\
\hline Kecamatan & Penduduk & Luas $\left(\mathrm{km}^{2}\right)$ \\
\hline$(1)$ & $(2)$ & $(3)$ \\
\hline Tinambung & 23.153 & 19,10 \\
\hline Balanipa & 24.583 & 34,9 \\
\hline Limboro & 17.272 & 63,22 \\
\hline Tubbi Taramanu & 19.067 & 441,84 \\
\hline Alu & 12.331 & 180,19 \\
\hline Campalagian & 53.926 & 128,35 \\
\hline Luyo & 27.795 & 124,27 \\
\hline Jumlah & $\mathbf{1 7 8 . 1 2 7}$ & $\mathbf{9 9 1 , 1 6}$ \\
\hline
\end{tabular}

Sumber : Badan Pusat Statistik Polewali Mandar, Polewali Mandar Dalam Angka 2017

Dari 7 ( Tujuh ) Kecamatan yang nantinya akan tergabung dalam wilayah Kabupaten Balanipa, Kecamatan yang memiliki desa dan kelurahan terbanyak yaitu Kecamatan Campalagian yang terdiri dari 19 Desa dan 1 Kelurahan. Sedangkan Kecamatan yang mempunyai jumlah desa dan kelurahan yang paling sedikit adalah Kecamatan Alu dan Tinambung yang hanya memiliki 7 Desa dan 1 Kelurahan. Dengan rincian sebagai berikut :

\begin{tabular}{|c|c|c|}
\hline \multicolumn{3}{|c|}{$\begin{array}{c}\text { Tabel 3 } \\
\text { Jumlah Desa dan Kelurahan Menurut Kecamatan } \\
\text { Persiapan Kabupaten Balanipa, 2015 }\end{array}$} \\
\hline Kecamatan & Desa & Kelurahan \\
\hline (1) & (2) & (3) \\
\hline Tinambung & 7 & 1 \\
\hline Balanipa & 10 & 1 \\
\hline Limboro & 10 & 1 \\
\hline Tubbi Taramanu & 12 & 1 \\
\hline Alu & 7 & 1 \\
\hline Campalagian & 19 & 1 \\
\hline Luyo & 10 & 1 \\
\hline Jumlah & 75 & 7 \\
\hline
\end{tabular}

Sumber : Badan Pusat Statistik Polewali Mandar, Polewali Mandar Dalam Angka 2017

\section{B. Dasar Hukum Pembentukan Kabupaten Balanipa}

Dasar hukum Pemerintah daerah adalah Undang-Undang Pemerintahan Daerah, dari Undang-Undang No. 5 Tahun 1974 menjadi Undang-Undang No. 22 Tahun 1999 serta Undang-Undang No. 32 Tahun 2004 dan Undang-Undang No 23 Tahun 2014 yang ditetapkan dengan Perubahan di Undang-Undang No 2 Tahun 2015.

Dasar Hukum Pembentukan Daerah dalam UUD 1945, BAB VI Pemerintahan Daerah Pasal 18 (1) Negara Kesatuan Republik Indonesia dibagi atas daerah-daerah propinsi dan daerah propinsi itu dibagi atas kabupaten dan kota, yang tiap-tiap propinsi,kabupaten, dan kota itu mempunyai pemerintahan daerah, yang diatur dengan undang-undang. Perubahan II 18 Agustus 2000, sebelumnya berbunyi : Pembagian daerah Indonesia atas daerah besar dan kecil dengan bentuk susunan pemerintahannya ditetapkan dengan Undang-undang, dengan memandang dan mengingati dasar 
permusyawaratan dalam sistim Pemerintahan Negara, dan hak-hak asal-usul dalam daerah yang bersifat istimewa.

Dasar Pembentukan Berikutnya Undang-Undang Nomor 32 Tahun 2004 tentang Pemerintahan Daerah (Lembaran Negara Republik Indonesia Tahun 2004 Nomor 125, Tambahan Lembaran Negara Republik Indonesia Nomor 4437) sebagaimana telah diubah dengan Undang-Undang Nomor 8 Tahun 2005 tentang Penetapan Peraturan Pemerintah Pengganti Undang-Undang Nomor 3 Tahun 2005 tentang Perubahan Atas Undang-Undang Nomor 32 Tahun 2004 tentang Pemerintah Daerah menjadi UndangUndang (Lembaran Negara Republik Indonesia Tahun 2005 Nomor 108, Tambahan Lembaran Negara Republik Indonesia Nomor 4548);

Dan dasar pembentukan daerah yang dituangkan PP RI No. 78 Tahun $2007 \mathrm{ttg}$ Tata Cara Pembentukan, Penghapusan, dan Penggabungan Daerah. (Ditetapkan di Jakarta pada tanggal 10 Desember 2007 Diundangkan di Jakarta pada tanggal 10 Desember 2007 LEMBARAN NEGARA REPUBLIK INDONESIA TAHUN 2007 NOMOR 162

Pembentukan Daerah Otonomi Baru (DOB) harus memenuhi syarat-syarat yang telah ditentukan dalam peraturan perundang-undangan. Dari hasil penelitian kami yang telah lakukan terkait dengan Rencana pembentukan kabupaten Balanipa apakah sudah memenuhi syarat-syarat berdasarkan Peraturan Perundang-Undangan (Undang undang Dasar Tahun 1945, Undang Undang Nomor 32 Tahun 2004 dan Peraturan Pemerintah Nomor 78 Tahun 2007) untuk di dimekarkan menjadi sebuah kabupaten, sesuai dengan hasil laporan Bupati Polewali Mandar didepan Komisi II DPR RI hari Senin 31 Januari 2011 sebagai berikut :

a. Sesuai Peraturan Pemerintah Nomor 78 Tahun 2007 Calon Kabupaten Balanipa sudah mendapat Keputusan persetujuan dari masyarakat dan BPD yang ada dimasing-masing wilayah yang akan menjadi cakupan wilayah Balanipa, Bupati dan DPRD Polewali Mandar, DPRD Provinsi dan Gubenur Provinsi Sulawesi Barat terkait persetujuan pembentukan calon Kabupaten Balanipa sebagai bagian dari persyaratan kelengkapan administrasi.

b. Untuk Syarat Fisik Kewilayahan, Calon Kabupaten Balanipa sebanyak 7 (tujuh) Kecamatan dan Kecamatan Balanipa merupakan peluang yang terbesar untuk dipertimbangkan menjadi calon lokasi Ibukota Kabupaten Balanipa, khususnya dilihat dari segi aspek tata ruang, ketersediaan fasilitas, aksesibilitas, kondisi dan letak geografis, kependudukan, social ekonomi, sosial politik, dan sosial budaya.

c. Sesuai PP No 78 Tahun 2007, untuk syarat Teknis yang meliputi faktor-faktor seperti Kependudukan, Kemampuan Ekonomi, Potensi Daerah, Kemampuan Keuangan, Sosial Budaya, Sosial Politik, Luas Daerah, Pertahanan, Keamanan, Tingkat Kesejahteraan Masyarakat, Dan Rentang Kendali.

\section{Peran masyarakat terhadap pembentukan Kabupaten Balanipa}

Semangat pembentukan Kabupaten Balanipa bergulir pada Medio November 2007, yang ditandai dengan lahirnya Komite Aksi Percepatan Pembetukan Kabupaten 
Balanipa (KAPP BALANIPA) dari kesepakatan Pertemuan Besar di gedung Tasha Centre di Tandung Tinambung. Pada Pertemuan ini juga sekaligus memutuskan HM.MUJIRIN M.YAMIN sebagai pemegang amanah utuk memimpin KAPP Balanipa untuk mengawal percepatan pemekaran Kabupaten Balanipa.

Upaya-upaya semakin gencar dilakukan, dan melahirkan keputusan DPRD Kab.Polewali Mandar No.3/KPTS/DPRD Tanggal 9 Juni 2008. Disusul kemudian keputusan Bapati No.191 Tahun 2008 tanggal 17 Juni 2008 tentang Persetujuan Pembentukan Kabupaten Balanipa sebagai hasil pemekaran Kabupaten Polewali Mandar. Begitupun Camat dan sejumlah Kepala Desa di wilayah ini bersepakat untuk melakukan upaya-upaya percepatan, termasuk yang perlu dicatat dalam perjuangan ini adalah responitas dari Pemerintah Kabupaten Induk berupa SK BUPATI Polewali Mandar No.72 Tahun 2009.

Munculnya elite-elite yang hadir sebagai pejuang pemekaran yang dengan alasan apapun mampu mendorong penyiapan proses proses menjadi sebuah kenyataan. Para Elite ini ternyata memegang peranan penting dalam membaca dan sekaligus menyikapi perkembangan tata pemerintahan. Elite ini juga belajar bagaimana menyikapi hadirnya regulasi dalam bentuk UU No. 32 tahun 2004 kemudian di ganti UU No. 23 tahun 2014 dan PP 78 tahun 2007.

Dinamika elite ini bukan saja sebatas bergerak pada teritori di mana ia berdomisili, tetapi juga membangun jejaring pada aras provinsi dan pusat. Jika dapat dikategorisaskan, maka para elite ini dapat dipilah dalam tiga kelompok, yakni: birokrasi, legislatif, tokoh masyarakat (civil society), dan gabungan dari ketiganya.

Muhammad Munir 25 Sep 2017 aktifis Appeq Jannangang :

"Dalam perjuangan ini, faktor pendorong harus lebih besar dari pada faktor penghambat sehingga masih terlalu dibutuhkan sebuah gerakan untuk membangun kesadaran kolektif menjadikan Balanipa sebagai milik bersama, pemimpin pergerakan yang memiliki daya dorong yang kuat, bargaining position yang tinggi serta tidak memiliki ketergantungan struktural kepada para pengambil kebijakan."

Lebih lanjut Abdul Rahim 15 Okt 2017 mengatakan bahwa :

"Kami akan selalu berjuang untuk mewujudkan Kabupaten Balanipa sebagai salah satu DOB di Provinsi Sulbar dan optimistis dapat terwujud tahun ini," kata Ketua Forum Mahasiswa Mandar Bersama yang merupakan organisasi mahasiswa pejuang pembentukan Provinsi Sulbar."

Beberapa alasan yang menjadikan tokoh masyarakat lebih dengan wacana Kabupaten Balanipa yakni masalah ketimpangan pembangunan daerah yang dirasakan masyarakat di Balanipa. Faktor tidak meratanya pembangunan sangat dirasakan oleh wilayah-wilayah yang bukan merupakan pusat kegiatan atau pusat pemerintahan (Ibukota).

Ketidakmerataan pembangunan bisa terjadi karena pihak elite birokrasi pemerintahan, legislatif, dan pelaku pembangunan yang kebanyakan tinggal di pusat pemerintahan, sering tidak memprioritaskan daerah pinggiran dan perbatasan untuk 
memperoleh jatah pembangunan yang adil. Pembangunan ekonomi Balanipa dalam ini tidak bisa ditawar dengan apapun. Muhammad Munir mengemukakan;

"Pembentukan Kabupaten Balanipa adalah gerakan yang berangkat dari dua pertimbangan: 1).Adanya appreciation disparity (Perbedaan perlakuan) antar Kawasan dan antara kelompok masyarakat di Kabupaten Polewali Mandar dalam jangka waktu yang sangat lama sehingga masyarakat dikawasan ini seolah tidak punya hak; Adanya kesenjangan Pembangunan antar kawasan di Polewali Mandar yang dirasakan sebagai sebuah ketidakadilan yang dilakukan oleh para penguasa Polewali mandar.Kondisi ini sangat berpengaruh secara phisikologis terhadap kegigihan para pejuang Pembentukan Kabupaten Balanipa.2.) Adanya Existing Condition dalam konteks Perjuangan Kabupaten Balanipa, seperti Kesenjangan pembangunan antar Kecamatan di Polewali Mandar khususnya Kecamatan Tutar, Luyo, Campalagian, Balanipa, Tinambung, Limboro dan Alu; Prosentase penduduk miskin Polewali Mandar tertinggi di Wilayah Sulawesi Barat sejak Tahun 2006 sampai 2010; Indeks Pembangunan Manusia(IPM) paling rendah di Sulbaradalah Polewali mandar sejak Tahun 2006-2010.Ketiga Kondisi inilah yang juga menjadi Pendorong Gerakan Perjuangan Pembentukan Kabupaten Balanipa.”

Tokoh masyarakat menganggap bahwa dengan dijadikannya Balanipa menjadi kabupaten, muncul kefokusan yang penuh dari pemerintah kabupaten untuk mengembangkan perekonomian Balanipa.

\section{Dukungan Pemerintah atas Pembentukan Kabupaten Balanipa.}

Berdasarkan Undang-Undang Nomor 32 Tahun 2004 tentang Pemerintahan Daerah, pembentukan daerah pada dasarnya bertujuan untuk meningkatkan pelayanan publik guna mempercepat terwujudnya kesejahteraan masyarakat.

Pembentukan daerah dapat berupa pemekaran dari satu daerah menjadi dua daerah atau lebih, atau penggabungan bagian daerah yang bersandingan, atau penggabungan beberapa daerah.

Proses pembentukan daerah didasari pada 3 (tiga) persyaratan, yakni administratif, teknis, dan fisik kewilayahan.

1. Persyaratan administratif didasarkan atas aspirasi sebagian besar masyarakat setempat untuk ditindaklanjuti oleh pemerintah daerah dengan melakukan kajian daerah terhadap rencana pembentukan daerah.

2. Persyaratan secara teknis didasarkan pada faktor kemampuan ekonomi, potensi daerah, sosial budaya, sosial politik, kependudukan, luas daerah, pertahanan, keamanan, dan faktor lain yang memungkinkan terselenggaranya otonomi daerah. Adapun faktor lain tersebut meliputi pertimbangan 
kemampuan keuangan, tingkat kesejahteraan masyarakat, dan rentang kendali penyelenggaraan pemerintahan.

3. Persyaratan fisik kewilayahan dalam pembentukan daerah meliputi cakupan wilayah, lokasi calon ibukota, sarana, dan prasarana pemerintahan.

Dengan persyaratan dimaksud diharapkan agar daerah yang baru dibentuk dapat tumbuh, berkembang dan mampu menyelenggarakan otonomi daerah dalam rangka meningkatkan pelayanan publik yang optimal guna mempercepat terwujudnya kesejahteraan masyarakat dan dalam memperkokoh keutuhan Negara Kesatuan Republik Indonesia.

Kajian daerah ini merupakan hasil kajian Tim yang dibentuk oleh kepala daerah yang bersangkutan untuk menilai kelayakan pembentukan daerah otonom baru secara obyektif yang memuat penilaian kuantitatif terhadap faktor-faktor teknis. Menurut Fahri Hamzah Wakil Ketua DPR RI mengatakan bahwa:

"DOB Balanipa layak sebab sesuai keinginan masyarakat setempat dan didukung unsur pemerintah dengan tujuan agar pembangunan di segala bidang lebih baik."

Hal serupa disampaikan oleh Anggota Komisi II DPR RI, Miryam S Haryani bahwa :

"Kami tetap siap mengawal dilakukan percepatan pemekaran DOB Balanipa. Hanya saja, Pemprov Sulbar dan Pemkab Polman selaku daerah induk harusnya lebih agresip lagi untuk mempersiapkan apa yang menjadi isyarat terjadinya pemekaran wilayah,"

Lebih lanjut menurut Asri Anas yang merupakan Tim Kajian DOB di DPD RI ini Dijelaskan, semua prosedur dan mekanisme untuk membentuk Kabupaten Balanipa telah terpenuhi. "Bahkan yang hadir di dalam rapat ini ada pak Bupati dan DPRD Polman hadir. Ini bentuk keseriusan kami di Sulbar untuk memekarkan Balanipa. DPD tidak mungkin menghalangi pemekaran Balanipa bahkan kami bersunggguh-sungguh untuk itu,".

Untuk percepatan Pembentukan Kabupaten Balanipa Komitmen DPD RI itu dibuktikan dengan melakukan kunker langsung ke wilayah calon DOB Balanipa. Rombongan Komite DPD yang khusus membidangi persoalan pemekaran daerah itu dipimpin langsung oleh Ketua Komite I DPD RI, Drs. H. Akhmad Muqowwam, diikuti 7 Anggota Komite I DPD RI, di antaranya, Muh. Asri Anas, A. Hudarni Rani, Nurmawati Dewi Bantilan, Abdul Azis Khafia, Jacop Esau Komigi, Antung Fatmawati dan Syafruddin Atasoge.

Beberapa faktor penyebab terjadinya pemekaran di antaranya adalah (a) faktorfaktor pendorong seperti (1) faktor kesejarahan, (2) faktor tidak meratanya pembangunan, (3) rentang kendali pelayanan publik yang jauh, dan (4) tidak terakomodasinya representasi politik, dan (b) faktor penarik, yaitu kucuran dana (fiskal) dari pusat. Sedangkan faktor yang memfasilitasi munculnya pemekaran di antaranya adalah: (1) Proses persiapan untuk mekar; (2) Political crafiting oleh paraelite; (3) Kondisi perpolitikan nasional; dan (4) faktor tuntutan keamanan daerah perbatasan (Murtir Jeddawi, 116: 2009). 
Dapat disimpulkan oleh penulis, dalam perjalanan pemekaran daerah, kepentingan politik dan elitnya ikut dipertaruhkan dalam proses pemekaran, selain faktor ketidakadilan ekonomi, politik juga motif yang sangat terlihat jelas dimana akan terjadi peluang perekrutan jabatan bagi elite lokal.

\section{Penutup}

\section{A. Kesimpulan}

Berdasarkan penelitian yang telah dilakukan baik yang berupa observasi atau hasil wawancara terhadap sejumlah informan sesuai dengan permasalah yang diteliti maka pada bagian ini dirumuskan kesimpulan hasil penelitian mengenai: Analisis SosioYuridis Pembentukan Kabupaten Balanipa adalah sebagai berikut:

1. Peran elite lokal Pembentukan daerah otonom Kabupaten Balanipa mengesankan pembangunan dan komunikasi pada Pemerintah pusat dengan proses penyiapan teknokratis/administrasi atas sejumlah kekurangan persyaratan morathorium Rancangan Undang-Undang (RUU). Kebijakan pemekaran daerah berdasar PP No. 78 Tahun 2007 justru lebih menekankan pada proses-proses ruang politik. Meskipun nampak ada sejumlah permasalahan mendasar yang dapat menyebabkan terjadinya pembentukan Kabupaten Balanipa namun demikian semua elite tersebut tidak akan mencapai hasil seperti sekarang kalau tidak ada campur tangan elite lokal, regional, dan pusat. Semua permasalahan tersebut merupakan kombinasi elite yang sangat kuat yang oleh elite lokal, regional, dan pusat.

2. Pada tingkat masyarakat perjuangan pembentukan Kabupaten Balanipa didasarkan pada kesadaran kolektif berbasis teritori-etnik dari tokoh masyarakat (civil society) memaksa mereka untuk bekerjasama dengan pejabat negara demi memperjuangan kejayaan masa lalu sebagai wilayah bekas kerajaan sebagai wilayah administrasi Kerajaan Balanipa. Landasan ide tersebut kemudian dijadikan upaya konsolidasi dengan para elite di atas lokal. Dimana peran masyarakat yakni mobilisasi massa sebagai bagian dari wujud aspirasi masyarakat dalam upaya mengontrol keputusan penetapan Pembentukan kabupaten Balanipa di ruang Rapat Badan Legislasi Nasional (Baleg) DPR RI pemerintah pusat.

Sehingga berdasarkan kenyataan adanya pembentukan Kabupaten Balanipa seperti terurai di muka menyebabkan munculnya sejumlah elite-elite yang memperjuangkan pemekaran. Para elite kemudian tergabung bersama para tokoh masyarakat juga berfungsi sebagai akselerator pemekaran. Proses yang dilakukan oleh para elite untuk memperjuangkan pemekaran adalah melakukan pengembangan jejaring dengan elite-elite negara (birokrasi) nasional.

\section{B. Saran}

Pembentukan Daerah otonomi baru (DOB) memang selalu menjadi bagian yang menarik dalam sistem perpolitikan nasional kita. Seringkali warna lahirnya kebijakan memecahkan wilayah kabupaten/kota maupun provinsi mengandung makna yang 
terselubung bagi posisi elite yang memegang peranan kunci di aras lokal. sehingga yang menjadi saran penulis dari hasil penelitian yang dilakukan yakni :

1. Pemerintah sebaiknya segera membuat aturan kebijakan yang bersifat spesifik menyangkut institusi mengenai perencanaan kelembagaan pembentukan daerah otonomi baru. Pembentukan daerah otonomi baru memang murni kemerdekaan masyarakat di daerah bukan kedaulatan kelompok elite.

2. Pembentukan kabupaten Balanipa sebagai contohnya, Pemekaran dua daerah, Kabupaten Balanipa dan Kabupaten Mamasa Tengah telah melahirkan catatan penting bagi pemerintah setempat.

4. Sekalipun secara administrasi pembentukan kabupaten telah disepakati oleh pemerintah setempat namun secara politik pro/kontra tetap saja lahir dalam kalangan elite. Sehingga penting sekali mengetahui dampak pemekaran harus menguntumkan kedua bela pihak baik kabupaten induk maupun kabupaten yang akan dibentuk (DOB). Karena pembentukan daerah otonom baru bertujuan untuk meningkatkan pelanyanan dan mengurangi kesenjangan social kepada masyarakat.

\section{Daftar Pustaka}

[1] Abdullah, Rozali. 2005. Pelaksanaan Otonomi Luas Dengan Pemilihan Kepala Daerah Secara Langsung. Jakarta: RajaGrafindo Persada

[2] Bungin, Burhan. 2011. Metode Penelitian Kualitatif. Jakarta: RajaGrafindo Persada

[3] Effendy, Khasan. 2009. Pengembangan Organisasi: Moratorium dan Morbidtarium Pemekaran. Bandung: CV. Indra Prahasta

[4] Hidayat, Syarif. 2009. Pro Kontra Pemekaran Daerah (Analisis Empiris). Yogyakarta: Total Media

[5] Jeddawi, Murtir. 2009. Pro Kontra Pemekaran Daerah (Analisis Empiris). Yogyakarta: Total Media

[6] Kaloh, J. 2007. Mencari Bentuk Otonomi Daerah. Jakarta: Rineka Cipta

[7] Makagansa H.R. 2008. Tantanagan Pemekaran Daerah. Yogyakarta: Fuspad

[8] Marbun, B.N. 2010. Otonomi Daerah 1945-2010, Proses dan Realita. Jakarta: Pustaka Sinar Harapan

[9] Ratnawati, Tri. 2009, Pemekaran daerah Politik Lokal dan Beberapa isu terseleksi. Yogyakarta : Pustaka Pelajar

[10] Riwu Kaho, Josef. Prospek Otonomi Daerah Di Negara Republik Indonesia. Jakarta: Raja Grafindo Persada

[11] Sabarno, Hari. 2008. Memandu Otonomi Daerah Menjaga Kesatuan Bangsa. Jakarta: Sinar Grafika

[12] Sugiyono. 2006. Metode Penelitian Kualitatif dan kuantitatif. Bandung: Alfabeta

[13] Suradinata, Ermaya. 2000. Pelaksanaan Otonomi Daerah Dalam Kerangka Untuk Meningkatkan Integritas Bangsa, Lembanga Ketahanan Nasional (Lemhanas). Kursus Singkat Angkatan (KSA)8. Lembaga Ketahanan Nasional, Departemen Pertahanan 
[14] Tim Redaksi. 2010. Perundang-undangan Tentang Otonomi Daerah. Yogyakarta: Pustaka Yustisia

[15]Warsisitiono, Sadu. 2007. Studi Kelayakan Pemekaran Wilayah Tangerang Selatan, Tinjauan Terhadap 36 Kecamatan dan Kondisi Batas Alam. Bandung, Jatinangor

[16] Widjaja, HAW. 2002. Otonomi Daerah Dan Daerah Otonom. Jakarta: RajaGrafindo Persada

[17]----------. 2003. Titik Berat Otonomi Pada Daerah Tingkat II. Jakarta: Raja Grafindo Persada

[18]-------------. 2005. Penyelenggaraan Otonomi Di Indonesia. Jakarta: RajaGrafindo Persada

[19]Undang-undang Republik Rndonesia Nomor 26 tahun 2004 Tentang Pembentukan Provinsi Sulawesi Barat

[20] Undang-Undang Nomor 11 Tahun 2002 tentang Pembentukan Kabupaten Polewali Mamasa

[21] Undang-Undang Nomor 32 Tahun 2004 tentang Pemerintahan Daerah

[22]Peraturan Pemerintah No.78 tahun 2007 tentang Tata Cara Pembentukan Penghapusan, dan Penggabungan Daerah

[23]Peraturan Pemerintah Nomor 129 Tahun 2000 tentang Tata Cara Pembentukan, Penghapusan, dan Penggabungan Daerah

[24] http://www.kemendagri.go.id/pages/profil/daerah/kabupaten/id/21/name/kepulauan -riau/detail/2101/bintan

[25] (http://butontengah.blogspot.com/2009/09/opini-pemekaran-daerah-ambisi-elitatau.html

[26] Wendra Yunaldi, SH., MH., Analisis Pemekaran Daerah, dimuat pada tanggal 15 Februari 2010, artikel ini (batamtoday.com/berita/37367-

[27] pengurus-BP2KBU-minta-ketua-umum-bp2kbt-mundur.html, diakses 5 Juli 2014, $07.06 \mathrm{Wib}$ ) 